\title{
Environmental monitoring of plutonium at ultratrace level in natural water (Sea of Galilee-Israel) by ICP-SFMS and MC-ICP-MS†
}

\author{
J. S. Becker, ${ }^{* a}$ M. Zoriy, ${ }^{a}$ L. Halicz, ${ }^{b}$ N. Teplyakov, ${ }^{b}$ Chr. Müller, ${ }^{a}$ I. Segal, ${ }^{b}$ \\ C. Pickhardt ${ }^{a}$ and I. T. Platzner ${ }^{b}$ \\ ${ }^{a}$ Central Division of Analytical Chemistry, Research Center Jülich, D-52425 Jülich, \\ Germany \\ ${ }^{b}$ Geological Survey of Israel, 30 Malkhe Ysrael St., Jerusalem 95501, Israel
}

Received 28th April 2004, Accepted 20th May 2004

First published as an Advance Article on the web 13th August 2004

\begin{abstract}
An analytical method for the determination of plutonium concentration and its isotope ratio at ultratrace level in natural water by inductively coupled plasma mass spectrometry (ICP-MS) is proposed. In order to preconcentrate $\mathrm{Pu}$ and to avoid matrix effects and clogging effects on the cones during the mass spectrometric measurements, an effective Pu separation procedure (on TEVA resin) from the matrix was applied. Studies of the separation procedure for $2.1 \mathrm{pg}$ of ${ }^{242} \mathrm{Pu}$ spiked into $100 \mathrm{~L}$ of lake water from the Sea of Galilee result in a recovery of $62 \%$. The detection limits of ${ }^{239} \mathrm{Pu}$ in $100 \mathrm{~L}$ lake water were determined as $1 \times 10^{-19} \mathrm{~g} \mathrm{~mL}^{-1}$ and $3 \times 10^{-20} \mathrm{~g} \mathrm{~mL}^{-1}$ using ICP-SFMS and MC-ICP-MS, respectively. ${ }^{239} \mathrm{Pu}$ was detected in the Sea of Galilee at a concentration level of about $3.6 \times 10^{-19} \mathrm{~g} \mathrm{~mL}^{-1}$ with a ${ }^{240} \mathrm{Pu} /{ }^{239} \mathrm{Pu}$ isotope ratio of 0.17 . This measured plutonium isotope ratio is the most probable evidence of plutonium contamination of the Sea of Galilee as a result of global nuclear fallout after the nuclear weapons tests in the sixties. This paper discusses applications of double-focusing sector field ICP-MS with single and multiple ion collection for the quantitative determination of plutonium and its isotope ratio at the $10^{-19} \mathrm{~g} \mathrm{~mL}^{-1}$ level in natural water.
\end{abstract}

\section{Introduction}

The Sea of Galilee is one of the three main potable water resources in Israel, supplying about $20 \%$ of national water consumption. Artificial pollution of the Sea of Galilee, also with long-lived radionuclides, has increased in the last few decades. Monitoring and identifying the origin of the longlived radionuclides would therefore be a powerful tool for understanding possible sources of contamination. ${ }^{1-5}$

The most widely used analytical techniques for the determination of $\mathrm{Pu}$ isotopes are radioanalytical techniques, such as $\alpha$-spectrometry or liquid scintillation radiometry. ${ }^{4,6}$ However, a long counting period, which can take from days to several weeks, depending on the sensitivity and precision required, ${ }^{2}$ significantly restricts usage of these techniques. In addition, radionuclide analysis of ${ }^{239} \mathrm{Pu}$ and ${ }^{240} \mathrm{Pu}$ by alpha spectrometry is very difficult, due to their similar alpha energies (5.24 and $5.25 \mathrm{MeV}$, respectively). Therefore, for accurate $\mathrm{Pu}$ isotope determination mass spectrometric techniques have to be established.

Accelerator mass spectrometry (AMS) ${ }^{7,8}$ and thermal ionization mass spectrometry (TIMS) ${ }^{9,10}$ have been used as ultrasensitive mass spectrometric techniques for $\mathrm{Pu}$ isotope analysis in different samples. However, AMS is very expensive and is not widely used. As an alternative to AMS, high-selective resonance ionization mass spectrometry (RIMS) was also applied for the determination of $\mathrm{Pu}$ at ultratrace level, ${ }^{11-13}$ but at present RIMS instruments are not available on the analytical market. In addition, in all the mass spectroscopic techniques mentioned above, the sample preparation procedure is very complicated and, therefore, time- and labor-consuming.

Inductively coupled plasma mass spectrometry is one of the most suitable methods for the ultratrace isotope analysis of actinides, ${ }^{14-16}$ in particular $\mathrm{Pu}$, due to its high sensitivity, good

$\dagger$ Presented at the 2004 Winter Conference on Plasma Spectrochemistry, Fort Lauderdale, FL, USA, January 5-10, 2004. accuracy and precision, and relatively simple sample preparation procedure. ${ }^{17,18} \mathrm{~A}$ number of papers devoted to the determination of $\mathrm{Pu}$ by ICP-MS in different samples have been published in recent years, ${ }^{3,19-23}$ which proves the capability of ICP-MS for the study of $\mathrm{Pu}$ at the ultratrace concentration level. However, uranium hydride formation $\left({ }^{238} \mathrm{U}^{1} \mathrm{H}^{+}\right)$and peak tailing from ${ }^{238} \mathrm{U}^{+}$are the limiting factors for the determination of ${ }^{239} \mathrm{Pu}$ at very low concentration levels in natural samples containing, relative to $\mathrm{Pu}$, high concentrations of natural uranium. Moreover, depending on the matrix of the analyzed sample, other molecular ions, such as molecular ions from lead or rare earth elements, which can be expected in the actinide mass range (e.g., $\mathrm{PbO}_{2}{ }^{+}, \mathrm{PbN}_{2}{ }^{+}$, etc. $),{ }^{24,25}$ will disturb the accurate determination of $\mathrm{Pu}$.

To avoid these problems, several solutions have been proposed. To reduce hydride formation of uranium special sample introduction systems, such as micronebulizers with desolvator, were applied, ${ }^{24}$ or heavy water for dilution of the samples was used. ${ }^{26}$ In order to reduce the peak tailing effect, the medium mass resolution of sector field mass spectrometer instrument was successfully applied. ${ }^{26}$

For $\mathrm{Pu}$ determination in sea-water, urine, waste water samples, etc., mostly the chemical separation of ultratrace plutonium from $\mathrm{U}$ as well as matrix elements has been proposed. Ion-exchange and extraction chromatography on the resin have been widely used in different laboratories for this purpose. . $^{2,25,27}$

Recently, Kim et al. ${ }^{27}$ studied ${ }^{239} \mathrm{Pu}$ and ${ }^{240} \mathrm{Pu}$ in sea-water using an on-line sequential injection technique with ICP-SFMS and an ultrasonic nebulizer USN 6000 for sample introduction. Limits of detection (LODs) for ${ }^{239} \mathrm{Pu}$ and ${ }^{240} \mathrm{Pu}$ of $0.64 \mathrm{fg} \mathrm{mL}^{-1}$ $\left(1.4 \times 10^{-6} \mathrm{~Bq} \mathrm{~mL}^{-1}\right)$ and $0.19 \mathrm{fg} \mathrm{mL}^{-1}\left(1.7 \times 10^{-6} \mathrm{~Bq} \mathrm{~mL}^{-1}\right)$, respectively, were achieved. In the Sea of Galilee, where the concentration of $\mathrm{Pu}$ is very low, further enrichment of this transuranium element is required for accurate analysis. For this purpose, a combination of co-precipitation with extraction chromatography separation has been successfully established 
in order to concentrate and separate $\mathrm{Pu}$ prior to analysis by $\alpha$-spectrometry ${ }^{28-30}$ or by ICP-MS. ${ }^{22,25}$ A very promising aspect of the plutonium determination is the use of multiple ion collector ICP-MS (MC-ICP-MS), which allows a 10-fold improvement in sensitivity and precision of isotope ratio measurements ${ }^{31-33}$ and becomes of extreme importance at the low concentration level of $\mathrm{Pu}$ in analysed samples.

The aim of this research is to develop and apply an analytical technique for ultrasensitive $\mathrm{Pu}$ determination and $\mathrm{Pu}$ isotope analysis at ultratrace level in lake water from the Sea of Galilee by double-focusing sector field ICP-MS (ICP-SFMS) and MCICP-MS after matrix separation and preconcentration.

\section{Experimental}

\section{ICP-MS instrumentation}

ICP-SFMS (ELEMENT, Thermo Electron GmbH, Bremen, Germany) was applied in the Central Division of Analytical Chemistry at the Research Center Juelich for Pu isotope ratio measurements in water samples from the Sea of Galilee. For sample introduction, the PFA-100 microconcentric nebulizer (CETAC Technologies, Inc., Omaha, NE, USA) was used. Aqueous solutions were introduced in the continuous flow mode using a peristaltic pump (Perimax 12, Spetec GmbH, Erding, Germany). The ICP torch was shielded with a grounded platinum electrode (GuardElectrode ${ }^{(i x}$, Thermo Electron GmbH, Bremen, Germany).

Comparative measurements of plutonium isotope ratio and concentration were performed using MC-ICP-MS with a NierJohnson geometry $(\mathrm{Nu}$ Instruments, $\mathrm{UK}$, installed at the Geological Survey of Israel, Jerusalem). A microconcentric nebulizer with an Aridus desolvator (CETAC Technologies, Inc., Omaha, NE, USA) was used for solution introduction in MC-ICP-MS

\section{Standards and reagents}

A laboratory standard solution of uranium NBS-3164 $\left(0.5 \mathrm{ng} \mathrm{mL} \mathrm{mL}^{-1}\right)$ with natural isotopic composition was used for optimization of the experimental parameters. For the determination of the precision and accuracy of ${ }^{240} \mathrm{Pu} /{ }^{239} \mathrm{Pu}$ isotope ratio measurements synthetically prepared aqueous laboratory isotope standard solution with known plutonium isotope composition $\left({ }^{240} \mathrm{Pu} /{ }^{239} \mathrm{Pu}=0.2960 \pm 0.0026\right.$, uncertainty $2 s$ ) was used. ${ }^{242} \mathrm{Pu}$ isotope standard (NIST SRM 4334F) was applied to control recovery of the developed procedure. Calibration standard solutions were prepared by dilution of $1 \mathrm{ng} \mathrm{mL}-1$ aqueous ${ }^{242} \mathrm{Pu}$ to the following concentrations of ${ }^{242} \mathrm{Pu}: 1,10,50,100,200,500$ and $1000 \mathrm{fg} \mathrm{mL} \mathrm{m}^{-1}$. $100 \mathrm{~L}$ of high-purity deionized water (18 $\mathrm{M} \Omega \mathrm{cm}^{-1}$ ), obtained from Milli-Q-Plus water purifier (Millipore Billerica, MA, USA), was subjected to the same co-precipitation and separation procedures as the sample in order to obtain the procedural blank.

All chemicals used were of supragrade (Merck, Darmstadt, Germany). Nitric acid was further purified by sub-boiling distillation.

\section{Sample preparation}

$100 \mathrm{~L}$ of water from the Sea of Galilee was collected in containers previously washed repeatedly with $2 \% \mathrm{v} / \mathrm{v}$ nitric acid in $18 \mathrm{M} \Omega \mathrm{cm}$ water. The water sample was filtered $(0.45 \mu \mathrm{m})$ in the field before acidification. The uranium concentration was $0.6 \mathrm{ng} \mathrm{mL}{ }^{-1}$. A schematic diagram of the sample preparation procedure is shown in Fig. 1.

Co-precipitation of Pu with $\mathbf{M n O}_{2}$. The $100 \mathrm{~L}$ water sample was acidified with nitric acid to $\mathrm{pH}=2$. In order to determine the recovery of the method the sample was spiked with $2.1 \mathrm{pg}$ of

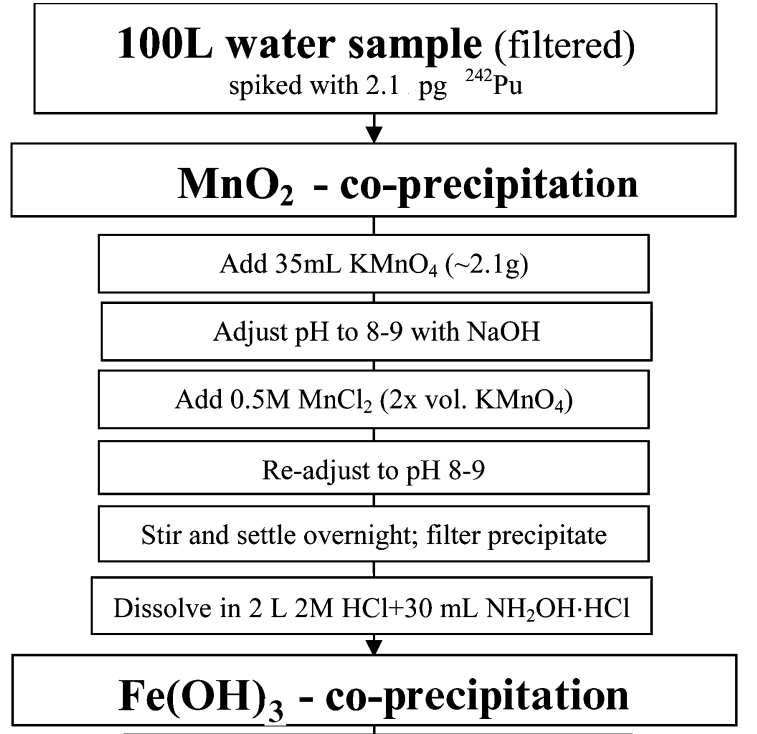

\begin{tabular}{|c|}
\hline Add $50 \mathrm{mg} \mathrm{Fe}^{3+}$ as $\mathrm{FeCl}_{3}$ \\
\hline Add $2 \mathrm{M} \mathrm{NaOH}$ to decrease acid conc. \\
\hline Add $\sim 2 \mathrm{~mL} \mathrm{NH}_{2} \mathrm{OH} \cdot \mathrm{HCl}$ \\
\hline Add $20 \mathrm{~mL} \mathrm{NaNO}_{2}\left(0.1 \mathrm{~g} \mathrm{~mL}^{-1}\right)$ \\
\hline Adjust to $\mathrm{pH} 8-9$ with $2 \mathrm{M} \mathrm{NH}_{4} \mathrm{OH}$ \\
\hline Allow $\mathrm{Fe}(\mathrm{OH})_{3}$ precipitate to settle \\
\hline Centrifugation 10 min at $4000 \mathrm{rpm}$ \\
\hline
\end{tabular}

Filter precipitate and dissolve in $11.2 \mathrm{~mL} 7 \mathrm{M} \mathrm{HNO}_{3}+4 \mathrm{~mL} 0.5 \mathrm{M} \mathrm{Al}\left(\mathrm{NO}_{3}\right)_{3}$

\section{Separation of Pu on TEVA resin}

Dilute with MilliO up to $25 \mathrm{~mL}$

Place $0.5 \mathrm{~g}$ TEVA in the cartridge, condition with $5 \mathrm{~mL} 3 \mathrm{M} \mathrm{HNO}_{3}$

Transfer sample through the column

Wash $3 \times$ with $10 \mathrm{~mL} 3 \mathrm{M} \mathrm{HNO}_{3}$

Elution $\mathrm{Pu}$

$15 \mathrm{~mL} 0.05 \mathrm{M} \mathrm{HF}+0.05 \mathrm{M} \mathrm{HNO}_{3}$

\section{ICP-MS measurements of Pu}

Fig. 1 Sample preparation procedure for $\mathrm{Pu}$ analysis in water samples from the Sea of Galilee.

\begin{abstract}
${ }^{242} \mathrm{Pu}$ and thoroughly mixed. Then $35 \mathrm{~mL}$ of $\mathrm{KMnO}_{4}(\sim 2.1 \mathrm{~g})$ was added. All $\mathrm{Pu}$ present in this step was oxidized to the $\mathrm{Pu}^{6+}$ oxidation form. The solution was adjusted to $\mathrm{pH}=8-9$ with $\mathrm{NaOH}$ and $0.5 \mathrm{M} \mathrm{MnCl}_{2}\left(2 \times\right.$ vol. of $\left.\mathrm{KMnO}_{4}\right)$ was added in order to precipitate $\mathrm{MnO}_{2}$. Ultratraces of $\mathrm{Pu}$ are coprecipitated together with $\mathrm{MnO}_{2}$. After settling of the $\mathrm{MnO}_{2}$ with co-precipitated $\mathrm{Pu}$ overnight it was filtered by gravity over the filter paper (cellulose nitrate filter, $0.45 \mu \mathrm{m}$, Sartorius, Goettingen, Germany) and dissolved in $2 \mathrm{~L}$ of $2 \mathrm{M} \mathrm{HCl}+$ $30 \mathrm{~mL}$ of $\mathrm{NH}_{2} \mathrm{OH} \cdot \mathrm{HCl}\left(0.1 \mathrm{~g} \mathrm{~mL}^{-1}\right)$.
\end{abstract}

Co-precipitation of $\mathrm{Pu}$ with $\mathrm{Fe}(\mathrm{OH})_{3}$. To the dissolved filtrate $50 \mathrm{mg}$ of $\mathrm{Fe}^{3+}$ as $\mathrm{FeCl}_{3}$ was added and the solution was neutralized with $2 \mathrm{M} \mathrm{NaOH}$. In order to reduce $\mathrm{Fe}^{3+}$ to 
$\mathrm{Fe}^{2+}$ and $\mathrm{Pu}^{6+}$ to $\mathrm{Pu}^{3+} \sim 2 \mathrm{~mL}$ of $\mathrm{NH}_{2} \mathrm{OH} \cdot \mathrm{HCl}$ was added. After that, $\mathrm{Pu}^{3+}$ was oxidized with $20 \mathrm{~mL}$ of $\mathrm{NaNO}_{2}$ $\left(0.1 \mathrm{~g} \mathrm{~mL}^{-1}\right)$ to $\mathrm{Pu}^{4+}$, since tetravalent $\mathrm{Pu}$ is more favorable for separation on TEVA resin. The solution was adjusted to $\mathrm{pH}=8-9$ with $2 \mathrm{M} \mathrm{NH}_{4} \mathrm{OH}$ and heated for $\sim 2$ hours $(60-$ $\left.70{ }^{\circ} \mathrm{C}\right)$ to improve coagulation of the $\mathrm{Fe}(\mathrm{OH})_{3}$ with co-precipitated $\mathrm{Pu}$. After that, the precipitate was settled, transferred to a centrifuge tube and centrifuged for approximately $10 \mathrm{~min}$ at $4000 \mathrm{rpm}$. The supernatant was decanted and discarded to waste; the precipitate was dissolved with $11.2 \mathrm{~mL}$ $7 \mathrm{M} \mathrm{HNO}_{3}+4 \mathrm{~mL} 0.5 \mathrm{M} \mathrm{Al}\left(\mathrm{NO}_{3}\right)_{3}$ and diluted with MilliQ water up to a volume of $\sim 25 \mathrm{~mL}$ so that a $3 \mathrm{M} \mathrm{HNO}_{3}$ solution was obtained.

Chemical separation of plutonium. Plutonium was separated from the $\mathrm{Fe}(\mathrm{OH})_{3}$ by extraction chromatography using Eichrom's TEVA resin (Eichrom Technologies, Inc. Darien, IL, USA; particle size 50-100 $\mu \mathrm{m}$, active component aliphatic quaternary amine). $0.5 \mathrm{~g}$ of TEVA resin was placed into the appropriate cartridge tubes and preconditioned with $5 \mathrm{~mL} 3 \mathrm{M}$ $\mathrm{HNO}_{3}$. After that the sample solution was loaded on resin and rinsed 3 times with $10 \mathrm{~mL}$ of $3 \mathrm{M} \mathrm{HNO}_{3}$. Then plutonium was eluted 3 times with $5 \mathrm{~mL}$ of $0.05 \mathrm{M} \mathrm{HF}+0.05 \mathrm{M} \mathrm{HNO}_{3}$ into a Teflon beaker. Because of the high concentration of $U$ in the separated sample (U concentration was about $0.5 \mathrm{ng} \mathrm{mL}^{-1}$ ), $\mathrm{Pu}$ was separated on the TEVA resin for a second time. After the first separation the $\mathrm{Pu}$ fraction was evaporated to dryness and the residue was dissolved with $11.2 \mathrm{~mL}$ of $7 \mathrm{M} \mathrm{HNO}_{3}$. Then, $4 \mathrm{~mL}$ of $0.5 \mathrm{M} \mathrm{Al}\left(\mathrm{NO}_{3}\right)_{3}$ was added, the sample solution was made up to $25 \mathrm{~mL}$ with $\mathrm{H}_{2} \mathrm{O}$ and then subjected to the same TEVA separation protocol as described above. The $\mathrm{Pu}$ concentration and the $\mathrm{Pu}$ isotope ratio were then measured by ICP-SFMS and MC-ICP-MS.

\section{Optimization of experimental parameters in ICP-MS and measurement procedure}

Optimization of the experimental parameters of the ICP-MS instrument was performed with respect to the maximum ion intensity of ${ }^{238} \mathrm{U}^{+}$and minimum background at $\mathrm{m} / \mathrm{z} 239 \mathrm{u}$ using a laboratory standard solution of uranium with natural isotopic pattern. Instrument operation conditions are summarized in Table 1. The dead time correction for the ICP-SFMS in these measurements was considered to be neglible in this study because of the low concentration of $\mathrm{Pu}$ in analysed sample (even for the highest concentration level in the standard calibration curve $\left(1000 \mathrm{fg} \mathrm{mL}^{-1}\right)$, the dead time correction is only $0.006 \%$ ). The mass bias factor (assuming an exponential correction $^{34}$ ) was found to be $0.0063 \pm 0.0015(n=6)$ using a $0.5 \mathrm{ng} \mathrm{mL}^{-1}$ NIST U500 standard solution. Because after the second separation of the sample on TEVA resin the uranium

Table 1 Optimized experimental conditions of double focusing ICPSFMS and MC-ICP-MS for determination of $\mathrm{Pu}$ in water sample from the Sea of Galilee

\begin{tabular}{|c|c|c|}
\hline & $\begin{array}{l}\text { ICP-SFMS } \\
\text { Element }\end{array}$ & $\begin{array}{l}\text { MC-ICP-MS } \\
\mathrm{Nu} \text { Instrument }\end{array}$ \\
\hline Nebulizer type & PFA-100 & Aridus \\
\hline RF power/W & 1199 & 1300 \\
\hline Cooling gas flow rate/L min ${ }^{-1}$ & 18 & 13 \\
\hline Auxiliary gas flow rate ${ }^{a} / \mathrm{L} \min ^{-1}$ & 1.04 & 1.3 \\
\hline Nebulizer gas flow $\operatorname{rate}^{a} / \mathrm{L} \min ^{-1}$ & 0.91 & 0.6 \\
\hline Sweep gas flow rate ${ }^{a} / \mathrm{L} \min ^{-1}$ & - & 3.8 \\
\hline Solution uptake rate/mL $\min ^{-1}$ & 0.58 & 0.08 \\
\hline Spray chamber temperature $/{ }^{\circ} \mathrm{C}$ & - & 70 \\
\hline Desolvator heating temperature $/{ }^{\circ} \mathrm{C}$ & - & 160 \\
\hline Scanning mode & Peak hopping & - \\
\hline Mass window $(\%)$ & 10 & - \\
\hline Mass resolution, $m / \Delta m$ & 300 & 300 \\
\hline
\end{tabular}

concentration did not exceed $5 \mathrm{pg} \mathrm{mL}^{-1}$, the influences of uranium hydride molecular ions, as well as the peak tailing effect from ${ }^{238} \mathrm{U}$, on the background of $\mathrm{m} / \mathrm{z} 239 \mathrm{u}$ were considered negligible after their subtraction. Between each run the nebulizer was washed with mixture of pure $0.5 \mathrm{M} \mathrm{HCl}$ and $0.05 \mathrm{M} \mathrm{HF}$.

For MC-ICP-MS two cycles were used in the simultaneous data collection mode. In the first cycle, two ion-counting collectors (IC0 and IC1) were used for ${ }^{242} \mathrm{Pu}^{+}$and ${ }^{240} \mathrm{Pu}^{+}$and IC2 alone for ${ }^{238} \mathrm{U}^{+}$measurements. In the second cycle, IC0 and IC1 were used for ${ }^{241} \mathrm{Pu}^{+}$and ${ }^{239} \mathrm{Pu}^{+}$ion collection, which means that ${ }^{239} \mathrm{Pu}$ and ${ }^{240} \mathrm{Pu}$ isotopes were not measured simultaneously as might be expected from the name multicollector-ICP-MS.

The zero measurements were made by deflecting the electrostatic analyzer potential. The mass bias of MC-ICPMS is in the range for plutonium of about $0.8 \%$ per mass unit. Further details of the instrumentation and measurement procedure are given elsewhere. ${ }^{14,33,35,36}$

\section{Results and discussion}

\section{Precision and accuracy of Pu measurement}

The precision and accuracy of the ${ }^{240} \mathrm{Pu} /{ }^{239} \mathrm{Pu}$ isotope ratio of the developed method were studied using a laboratory $\mathrm{Pu}$ isotope standard solution (see Table 2). The results show sufficient agreement between the expected and measured values of the ${ }^{240} \mathrm{Pu} /{ }^{239} \mathrm{Pu}$ isotopic ratio with a precision ( $\mathrm{RSD}, n=10$ ) and accuracy of $0.9 \%$ and $1.3 \%$, respectively, which are comparable to our previous results. ${ }^{14}$ For ten independent measurements of $100 \mathrm{fg} \mathrm{mL}^{-1}$ of ${ }^{242} \mathrm{Pu}$ solution a precision of ion intensity of $5 \%$ was determined.

\section{Co-precipitation of plutonium}

${ }^{242} \mathrm{Pu}$ spike was used to indicate the efficiency of the coprecipitation and separation of the plutonium in the developed method. A concentration of dissolved plutonium in $100 \mathrm{~L}$ of water sample from the Sea of Galilee was approximately $2.1 \times$ $10^{-17} \mathrm{~g} \mathrm{~mL}^{-1}\left(5 \times 10^{-9} \mathrm{~Bq} \mathrm{~mL}^{-1}\right)$. Therefore, for the determination of $\mathrm{Pu}$ at a low (such as ag $\mathrm{mL}^{-1}$ ) concentration level further preconcentration steps are required. In addition, during these steps the matrix elements were removed (see Table 3), thus avoiding clogging effects of the solution introduction system and cones, matrix effects, etc. Using a co-precipitation procedure based on $\mathrm{MnO}_{2}$ and $\mathrm{Fe}(\mathrm{OH})_{3}$, concentration factors of more than 6600 were achieved.

\section{Uranium interferences on Pu determination}

Because of the presence of uranium in the analyzed sample (see Table 3) the accurate determination of ${ }^{239} \mathrm{Pu}$ by ICP-MS was difficult due to interferences from ${ }^{238} \mathrm{U}^{1} \mathrm{H}^{+}$ion formation and the peak tailing effect from ${ }^{238} \mathrm{U}^{+}$. These interferences led to an increase in the background signal of $\mathrm{m} / \mathrm{z} 239$ u (see Fig. 2), therefore necessitating separation of uranium from plutonium, especially if the uranium concentration is $>5 \mathrm{pg} \mathrm{mL}^{-1}$. In ICPSFMS and MC-ICP-MS, the hydride formation rate $\mathrm{UH}^{+} / \mathrm{U}^{+}$ was measured at $1 \times 10^{-4}$ and $2 \times 10^{-7}$, respectively.

Table $2{ }^{240} \mathrm{Pu} /{ }^{239} \mathrm{Pu}$ isotopic ratio in synthetically prepared laboratory standard solution measured by ICP-SFMS (ELEMENT)

\begin{tabular}{lllll}
\hline & \multicolumn{2}{l}{${ }^{240} \mathrm{Pu} /{ }^{239} \mathrm{Pu}$ isotopic ratio } & Precision \\
\cline { 2 - 5 } Nebulizer & Measured & Expected & $\begin{array}{l}\text { Accuracy } \\
(\%)\end{array}$ & $(\%)$ \\
\hline PFA-100 & $0.3002 \pm 0.0038$ & $0.2960 \pm 0.0026$ & 0.9 & 1.3 \\
\hline
\end{tabular}


Table 3 Concentration of major matrix elements and uranium in water samples from the Sea of Galilee before co-precipitation and after separation on TEVA resin measured by ICP-SFMS

\begin{tabular}{|c|c|c|c|}
\hline \multirow[b]{2}{*}{ Element } & \multicolumn{3}{|c|}{ Concentration $/ \mu \mathrm{g} \mathrm{mL}^{-1}$} \\
\hline & Sea of Galilee & $\begin{array}{l}\text { After } \mathrm{Pu} \\
\text { separation }\end{array}$ & $\begin{array}{l}\text { Decontamination } \\
\text { factor }^{a}\end{array}$ \\
\hline $\mathrm{Na}$ & $131.2 \pm 2.1$ & $1.10 \pm 0.02$ & 120 \\
\hline $\mathrm{Mg}$ & $35.0 \pm 0.8$ & $0.48 \pm 0.2$ & 75 \\
\hline $\mathrm{Ca}$ & $50 \pm 1$ & $0.11 \pm 0.01$ & 455 \\
\hline $\mathrm{U}$ & $(0.64 \pm 0.01) 10^{-3}$ & $(1.1 \pm 0.05) 10^{-6}$ & 582 \\
\hline
\end{tabular}

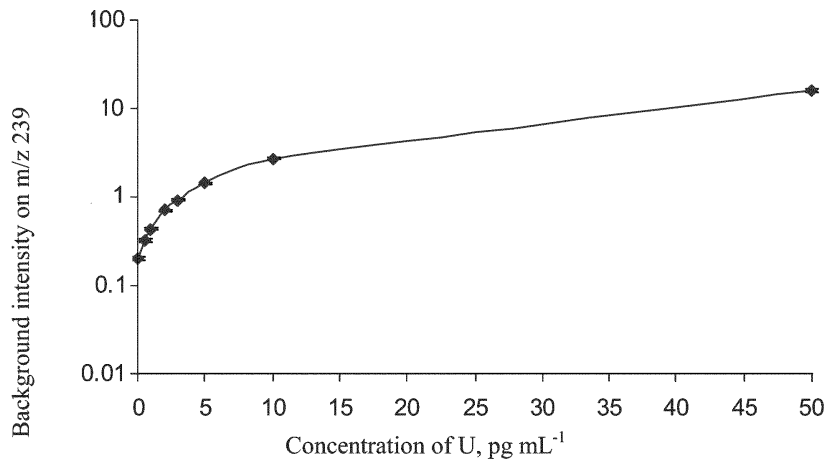

Fig. 2 Influence of $U$ concentration on the background signal on $\mathrm{m} / \mathrm{z}$ $239 \mathrm{u}$ in ICP-SFMS.

\section{Separation of plutonium on TEVA resin}

From the $\mathrm{Fe}(\mathrm{OH})_{3}$ precipitate plutonium was further separated from the uranium as well as matrix elements of the precipitate (mainly $\mathrm{Fe}$ and $\mathrm{Na}$ ) by means of extraction chromatography using Eichrom's TEVA resin. Moreover, because after separation the concentration of uranium was about $0.5 \mathrm{ng} \mathrm{mL}^{-1}$, the plutonium fraction was separated for the second time on TEVA resin. The total efficiency of the co-precipitation and two separation procedures in terms of the removal of matrix ions, as well as uranium, is shown in Table 3. The U concentration was determined as $1.1 \mathrm{pg} \mathrm{mL}^{-1}$, and no increase in the background at $m / z 239 \mathrm{u}$ was observed. The procedural recovery of ${ }^{242} \mathrm{Pu}$ spike was found to be about $62 \%$.

\section{Pu concentration in the Sea of Galilee}

After separation on TEVA resin, the water sample from the Sea of Galilee was measured by ICP-SFMS and MC-ICP-MS with respect to its plutonium content. The data, presented in Table 4, show a good agreement between the measurements on the two available instruments. The concentrations of ${ }^{239} \mathrm{Pu}$ in the Sea of Galilee were determined by short-term repeatability as $0.33 \pm 0.1 \times 10^{-18} \mathrm{~g} \mathrm{~mL}^{-1}\left(7.5 \times 10^{-10} \mathrm{~Bq} \mathrm{~mL}^{-1}\right)$ and $0.39 \pm 0.01 \times 10^{-18} \mathrm{~g} \mathrm{~mL}^{-1}\left(8.9 \times 10^{-10} \mathrm{~Bq} \mathrm{~mL}^{-1}\right)$, using ICP-SFMS and MC-ICP-MS, respectively. The LODs assuming the $3 \sigma$-criteria for ${ }^{239} \mathrm{Pu}$ and ${ }^{240} \mathrm{Pu}$ in $100 \mathrm{~L}$ water from the Sea of Galilee were determined as $1.2 \times 10^{-19} \mathrm{~g} \mathrm{~mL}^{-1}$ and $1.3 \times 10^{-19} \mathrm{~g} \mathrm{~mL}^{-1}$ for ICP-SFMS, respectively, and $1.3 \times$ $10^{-20} \mathrm{~g} \mathrm{~mL}^{-1}$ for both isotopes with MC-ICP-MS. The

Table 4 Concentration of ${ }^{239} \mathrm{Pu}$ and ${ }^{240} \mathrm{Pu} /{ }^{239} \mathrm{Pu}$ isotopic ratio measurements in the water sample from the Sea of Galilee, measured by ICP-SFMS (ELEMENT) and MC-ICP-MS (Nu Instuments)

\begin{tabular}{llll}
\hline ICP-MS & Nebulizer & $\mathrm{g} \mathrm{mL}^{239} \mathrm{Pu}$ concentration/ & ${ }^{240} \mathrm{Pu} /{ }^{239} \mathrm{Pu}$ \\
\hline ICP-SFMS & PFA-100 & $(3.3 \pm 1.0) 10^{-19}$ & $<0.33$ \\
MC-ICP-MS & Aridus & $(3.9 \pm 0.1) 10^{-19}$ & $0.17 \pm 0.05$ \\
\hline
\end{tabular}

intensity value of the procedural blank was applied for the evaluation of LODs and was always subtracted from the sample results.

\section{${ }^{240} \mathrm{Pu} /{ }^{239} \mathrm{Pu}$ isotope ratio measurement in the Sea of Galilee water at ultratrace level}

The optimized analytical method was applied to the measurement of the ${ }^{240} \mathrm{Pu} /{ }^{239} \mathrm{Pu}$ isotopic ratio in water from the Sea of Galilee after Pu matrix separation. Comparative measurements performed by ICP-SFMS and MC-ICP-MS are summarized in Table 4. The ${ }^{240} \mathrm{Pu} /{ }^{239} \mathrm{Pu}$ isotopic ratio measured by MC-ICPMS was determined as $0.17 \pm 0.05$, which represents the value of contamination of the Sea of Galilee due to the global fallout after nuclear weapon tests in the sixties. Using ICP-SFMS, the ${ }^{240} \mathrm{Pu} /{ }^{239} \mathrm{Pu}$ isotopic ratio was found to be $<0.33$, whereby ${ }^{240} \mathrm{Pu}$ has been measured below the detection limit. Due to the very low concentration of ${ }^{240} \mathrm{Pu}$ in the sample and a higher detection limit of ICP-SFMS with a single ion collector, we are not able to measure the ${ }^{240} \mathrm{Pu} /{ }^{239} \mathrm{Pu}$ isotopic ratio at $10^{-19} \mathrm{~g} \mathrm{~mL}^{-1}$ level in comparison with MC-ICPMS. Therefore, MC-ICP-MS has the advantage of analyzing the ${ }^{240} \mathrm{Pu} /{ }^{239} \mathrm{Pu}$ isotopic ratio with sufficient precision at the low ag $\mathrm{mL}^{-1}$ concentration level. In future, processing of the larger sample volume could be of interest in order to obtain more precise ${ }^{240} \mathrm{Pu} /{ }^{239} \mathrm{Pu}$ isotopic ratio.

\section{Conclusions}

This study demonstrates that double-focusing sector field ICPMS with single and multiple ion collection, combined with preconcentration and matrix separation, represents a useful analytical technique suitable for the analysis of plutonium in water at the low $10^{-18} \mathrm{~g} \mathrm{~mL}^{-1}$ level. Disturbing interferences affecting the accurate determination of $\mathrm{Pu}$ that arise from the presence of $U$ in the analyzed sample, as well as matrix elements, were successfully removed by co-precipitation and separation of the sample on Eichrom's TEVA resin. The limits of detection using ICP-SFMS and MC-ICP-MS achieved for ${ }^{239} \mathrm{Pu}$ in $100 \mathrm{~L}$ of lake water were $1.2 \times 10^{-19} \mathrm{~g} \mathrm{~mL}^{-1}$ and $3 \times$ $10^{-20} \mathrm{~g} \mathrm{~mL}^{-1}$, respectively. The recovery obtained for $2.1 \mathrm{pg}$ of ${ }^{242} \mathrm{Pu}$ dissolved in $100 \mathrm{~L}$ of water from the Sea of Galilee (concentration of ${ }^{242} \mathrm{Pu}: 21$ ag $\mathrm{mL}^{-1}$ ) was about $62 \%$. Measured by ICP-SFMS and MC-ICP-MS, concentrations of ${ }^{239} \mathrm{Pu}$ in the Sea of Galilee were $3.3 \pm 0.5 \times 10^{-19} \mathrm{~g} \mathrm{~mL}^{-1}$ $\left(7.5 \times 10^{-10} \mathrm{~Bq} \mathrm{~mL}^{-1}\right)$ and $3.9 \pm 0.1 \times 10^{-19} \mathrm{~g} \mathrm{~mL}^{-1}(8.9 \times$ $10^{-10} \mathrm{~Bq} \mathrm{~mL}{ }^{-1}$, respectively. Using the method presented in this study, the ${ }^{240} \mathrm{Pu} /{ }^{239} \mathrm{Pu}$ isotopic ratio in the Sea of Galilee was determined as $0.17 \pm 0.05$, which is the most probable evidence of plutonium contamination of the Sea of Galilee as a result of global nuclear fallout after nuclear weapons tests in the sixties.

\section{Acknowledgements}

The authors from Germany and Israel would like to thank the Bundesministerium für Bildung und Forschung (BMBF) for financially supporting the bilateral BMBF-MOST cooperation in Water Technology.

\section{References}

1 J. S. Becker, Spectrosc. Eur., 2002, 14, 8-16.

2 S. F. Boulyga, D. Desideri, M. A. Meli, C. Testa and J. S. Becker, Int. J. Mass Spectrom., 2003, 226, 329-339.

3 S. F. Boulyga, M. V. Zoriy, M. E. Ketterer and J. S. Becker, J. Environ. Monit., 2003, 5, 661-666.

4 E. Hrnecek, L. Aldave, L. Heras and M. Betti, Radiochim. Acta, 2002, 90, 721-725.

5 P. R. Danesi, A. Blaise, W. Burkart, T. Cabianca, M. J. Campbell, 
M. Makarewicz, J. Moreno, C. Tuniz and M. Hotchkis, J. Environ. Radioact., 2003, 64, 121-131.

6 C. Testa, G. Jia, S. Degetto, D. Desideri, F. Guerra, M. A. Meli and C. Roselli, Sci. Total Environ., 1999, 232, 27-31.

7 C. Vockenhuber, I. Ahmad, R. Golser, W. Kutschera, V. Liechtenstein, A. Priller, P. Steier and S. Winkler, Int. J. Mass. Spectrom., 2003, 223, 713-732.

8 S. H. Lee, J. Gastaud, J. J. La Rosa, L. L. W. Kwong, P. P. Povinec, E. Wyse, L. K. Fifield, P. A. Hausladen, L. M. Di Tada and G. M. Santos, J. Radioanal. Nucl. Chem., 2001, 248, 757-764.

9 P. W. Krey and K. W. Nicholson, J. Radioanal. Nucl. Chem., 2001, 248, 605-610.

10 D. Lewis, G. Miller, C. J. Duffy, D. W. Efurd, W. C. Inkret and S. E. Wagner, J. Radioanal. Nucl. Chem., 2001, 249, 115-120.

11 K. Wendt, N. Trautmann and B. A. Bushaw, Nucl. Instrum. Methods Phys. Res. B, 2000, 172, 162-169.

12 M. Nunnemann, N. Erdmann, H. U. Hasse, G. Huber, J. V. Kratz, P. Kunz, A. Mansel, G. Passler, O. Stetzer, N. Trautmann and A. Waldek, J. Alloys Comp., 1998, 271, 45-48.

13 N. Erdmann, M. Nunnemann, K. Eberhardt, G. Herrmann, G. Huber, S. Kohler, J. V. Kratz, G. Passler, J. R. Peterson, N. Trautmann and A. Waldek, J. Alloys Comp., 1998, 271, 837840.

14 J. S. Becker and H.-J. Dietze, J. Anal. At. Spectrom., 1999, 14, 1493.

15 J. S. Becker, J. Anal. At. Spectrom., 2002, 17, 1172-1185.

16 J. S. Becker, Spectrochim. Acta, Part B, 2003, 58, 1757-1784.

17 J. S. Becker and H.-J. Dietze in Encyclopedia of Analytical Chemistry, John Wiley, Chichester, UK, 2000, pp. 12947-12961.

18 A. Montaser, Inductively Coupled Plasma Mass Spectrometry, Wiley-VCH, New York, 1998.

19 D. Desideri, M. A. Meli, C. Roselli, C. Testa, S. F. Boulyga and J. S. Becker, Anal. Bioanal. Chem., 2002, 374, 1091-1095.

20 S. F. Boulyga, C. Testa, D. Desideri and J. S. Becker, J. Anal. At. Spectrom., 2001, 16, 1283-1289.
21 T. C. Kenna, J. Anal. At. Spectrom., 2002, 17, 1471-1479.

22 A. E. Eroglu, C. W. McLeod, K. S. Lenard and D. McCubbin, Spectrochim. Acta, Part B, 1998, 53, 1221-1233.

23 M. E. Ketterer, K. M. Hafer, C. L. Link, D. Kolwaite, J. Wilson and J. W. Mietelski, J. Anal. At. Spectrom., 2004, 19, 241-245.

24 J. S. Becker and H.-J. Dietze, Fresenius' J. Anal. Chem., 1999, 364, 482-488.

25 M. V. Zoriy, C. Pickhardt, P. Ostapczuk, R. Hille and J. S. Becker, Int. J. Mass. Spectrom., 2004, 232, 217-224.

26 M. V. Zoriy, L. Halicz, M. E. Ketterer, C. Pickhardt, I. Segal, P. Ostapczuk and J. S. Becker, J. Anal. At. Spectrom., 2004, 19, 362-367.

27 C. S. Kim and C. K. Kim, Anal. Chem., 2002, 74, 3824-3832.

28 D. Solatie, P. Carbol, E. Hrnecek, T. Jaakkola and M. Betti, Radiochim. Acta, 2002, 90, 447-454.

29 J. H. Kaye, R. S. Strebin and R. D. Orr, J. Radioanal. Nucl. Chem., 1995, 194, 191-196.

30 A. Comosa and S. Chibowski, J. Radioanal. Nucl. Chem., 2002, 251, 113-117.

31 R. N. Taylor, T. Warneke, J. A. Milton, I. W. Croudace, P. E. Warwick and R. W. Nesbitt, J. Anal. At. Spectrom., 2001, 16, 279-284.

32 R. N. Taylor, T. Warneke, J. A. Milton, I. W. Croudace, P. E. Warwick and R. W. Nesbitt, J. Anal. At. Spectrom., 2003, 18, 480-484.

33 I. Segal, L. Halicz and I. T. Platzner, Int. J. Mass Spectrom., 2002, 216, 177-184.

34 P. D. P. Taylor, P. De Bievre, A. J. Walder and A. Entwistle, J. Anal. At. Spectrom., 1995, 10, 395-399.

35 J. S. Becker and H.-J. Dietze, Fresenius' J. Anal. Chem., 2000, 368, 23-30.

36 I. T. Platzner, S. Ehrlich and L. Halicz, Fresenius' J. Anal. Chem., 2001, 370, 624. 